\section{AUTHORS:}

Ernest Dube ${ }^{1}$

Toi J. Tsilo²

Nondumiso Z. Sosibo² iD

Morris Fanadzo ${ }^{3}$ iD

\section{AFFILIATIONS:}

${ }^{1}$ School of Natural Resource

Management, Nelson Mandela

University, George, South Africa

${ }^{2}$ Agricultural Research Council -

Small Grain Institute, Bethlehem,

South Africa

${ }^{3}$ Department of Agriculture, Cape

Peninsula University of Technology,

Wellington, South Africa

\section{CORRESPONDENCE TO:}

Ernest Dube

EMAIL:

ernest.dube@mandela.ac.za

DATES:

Received: 03 May 2019

Revised: 28 July 2019

Accepted: 17 Sep. 2019

Published: 29 Jan. 2020

\section{HOW TO CITE:}

Dube E, Tsilo TJ, Sosibo NZ,

Fanadzo M. Irrigation wheat

production constraints and

opportunities in South Africa. S Afr

2020:116(1/2), Art. \#6342,

6 pages. https://doi.org/10.17159/

sajs.2020/6342

\section{ARTICLE INCLUDES:}

囚 Peer review

$\square$ Supplementary material

\section{DATA AVAILABILITY:}

$\square$ Open data set

$\square$ All data included

冈 On request from author(s)

$\square$ Not available

$\square$ Not applicable

EDITOR:

Teresa Coutinho iD

\section{KEYWORDS:}

exploratory research, food security,

policy, research, yield potential

FUNDING:

The Winter Cereal Trust, National Research Foundation (South Africa)

(C) 2020. The Author(s). Published under a Creative Commons Attribution Licence.

\title{
Irrigation wheat production constraints and opportunities in South Africa
}

\begin{abstract}
South Africa currently faces a wheat production crisis, suggesting that current policies, research and development projects may not be well aligned to farmer priorities. Through exploratory research, which included field inspections and farmer and researcher interviews, we identified the major constraints to irrigation wheat yield and explored opportunities for improving the yield and farmer profits. The dominant constraint to yield was identified as the low market price for grain, which makes farmers reluctant to invest in inputs for increasing wheat yield. Poor cultivar choice, cereal-based monocropping, the high cost of irrigation, inadequate irrigation water, low crop stands, soil acidity, no-till practices and red-billed quelea (Quelea quelea) birds are negatively impacting yields. Most importantly, we highlight a misalignment between current research efforts and farmer priorities. Recommendations for corrective measures necessary to improve yield and farmer profits are provided. This new knowledge will be useful to policymakers and researchers for better orienting investments in research and development projects aimed at addressing the current wheat production crisis in the country.

\section{Significance:}

- We highlight a misalignment between current research efforts and farmer priorities in the wheat sector, and provide new knowledge for better orienting investments in research and development projects aimed at addressing the current wheat production crisis.
\end{abstract}

\section{Introduction}

South Africa, like other developing countries, faces the challenge of an increasing population and food insecurity. The national yield of wheat (Triticum aestivum L.) decreased by approximately 740000 tons between 2002 and $2012,{ }^{1}$ leaving a gap of approximately 1 million tons annually, which had to be imported. This trend has continued to the present. A continual decline in wheat production has drawn the attention of both policymakers and researchers. According to the Agricultural Policy Action Plan for 2015-2019, this situation is alarming as the dependency on imported wheat is likely to increase. As such, Vision 2030 of the National Development Plan argues that 'research and development projects in the wheat sector are not coordinated, and alignment to government and industry priorities needs to be improved on'2. There are basically two options for increasing wheat production in South Africa: to expand the area under production (horizontal expansion) and to increase yields of existing croplands (vertical expansion). This also must be done in ways that are economically, environmentally and socially sustainable. The increase is unlikely to come from horizontal expansion due to competing land uses from other equally important agricultural sectors.

In this article, we address possibilities for vertical expansion, through a belief that there remains untapped potential to improve irrigation wheat yields and farmer profits in South Africa. Yield gap refers to the difference between the attainable yield and the actual yield. ${ }^{3}$ A preliminary study on yield gaps of irrigation wheat in South Africa showed that while yield averages ranged from $6.0 \mathrm{t} / \mathrm{ha}$ to $8.3 \mathrm{t} / \mathrm{ha}$, the yield potential ranged from $7.6 \mathrm{t} / \mathrm{ha}$ to $11.5 \mathrm{t} / \mathrm{ha}{ }^{4}$ Conclusions were that irrigation wheat yields could be increased by $26-38 \%$ in the major production areas of South Africa. However, information presented in the yield gap studies was not conclusive regarding solutions for closing the yield gaps.

If there is a need to understand the challenges faced by farmers, it makes the most sense to ask the farmers. Therefore, in search of strategies for increasing irrigation wheat yields and farm profits, exploratory research was carried out to obtain more information on the technical, biophysical and policy constraints of irrigation wheat yield. Exploratory research is conducted for a problem that has not been studied more clearly, with the aim of establishing priorities that may include development of a new research agenda. In this case, research was done through farmer interviews and field observations. The surveys were conducted in collaboration with the National Wheat Cultivar Evaluation Programme (NWCEP) during the 2015/2016 and 2016/2017 wheat production seasons. It was hoped that new knowledge on wheat yield constraints would be revealed, as a step towards identifying solutions to South Africa's wheat production challenge.

As alluded to previously, wheat production is on the decline in South Africa, suggesting that policies, research and development efforts in the industry are likely not aligned with farmer priorities. Hence, this study was extended to also answer the question: Are wheat scientists and policymakers well informed regarding the most important yield constraints on wheat fields in South Africa? It should be noted that the goal of this study was not to criticise wheat researchers, but to propose a new research agenda for the wheat industry - one that is well aligned to farmer priorities, yet builds on the current scientific knowledge.

\section{Methodology}

\section{Farm inspections and farmer interviews}

The irrigation wheat industry is made up of mostly large-scale commercial farmers, and the smallholder sector is virtually non-existent. From a commercial farmer perspective, production constraints can be classified as either biophysical, technical or policy related. Biophysical factors include climate, soils, water and pests. Technical constraints are related to tillage practices, cultivar choice, fertiliser use, pest management and other production 
practices. Policy issues have to do with market price for wheat, as well as input cost and supply, which can be influenced by various policies.

Annually, the Agricultural Research Council - Small Grain (ARC-SG) conducts the NWCEP in all the major irrigation wheat production areas of South Africa, in collaboration with wheat farmers. Representative producers in the cooler central, eastern highveld, KwaZulu-Natal and warmer northern irrigation areas (Figure 1) were identified from the NWCEP. Surveys were conducted by means of diarised face-to-face discussions and telephonic interviews. Ethical clearance was provided by the ARC-SG Research Planning Committee. A purposive sampling strategy was used, as only those farmers who gave researchers permission to visit their wheat fields were considered for this study. Over a period of 2 years, the NWCEP provided opportunity to interview various wheat farmers as well as survey representative irrigation wheat fields in search of yield constraints. A total of 162 farms of wheat grown under centre pivots were surveyed for the study (130 in 2015/2016 and 32 in 2016/2017). The field inspections and interviews were aimed at attempting to understand the way that production practices for wheat are carried out by the farmers. These important production practices are land preparation (tillage or no-till), seeding rates, pest control, fertiliser application, crop rotation, irrigation and yields. In total, 32 farmers were interviewed and expressed their views regarding major constraints to yield on their fields. Wheat cultivar performance and soil fertility data discussed in this article are derived from the on-farm wheat cultivar performance guidelines that are published by the ARC-SG annually. The data are also available online from the ARC website (http://www. arc. agric.za/arc-sgi/Pages/ARC-SGI-Homepage.aspx).

\section{Research scientist and industry expert interviews}

Researchers and industry experts interviewed for this study included wheat researchers, experienced employees of various wheat breeding companies, university lecturers who are experienced on wheat, as well as retired personnel who worked in the wheat industry. The data were collected by means of a questionnaire distributed via email. The key question addressed in the questionnaire related to perceptions on the most important yield constraints of irrigated wheat on production lands in South Africa. From the 100 questionnaires distributed, we received 47 responses. Areas of specialisation of the respondents were crop protection (53.1\%), plant breeding (4.3\%), agronomy (38.3\%) and wheat processing (4.3\%).

\section{Results and discussion}

\section{Farmers' perspective on causes of yield loss}

The yield potential of irrigation wheat is attained through planting the best cultivar for the area, use of quality seeds at the correct seeding rate, proper timing of planting, good land preparation, optimal plant stands, balanced fertiliser use, rational irrigation, as well as adequate control of pests. The effectiveness with which these practices are implemented determines the yields obtained by the farmers. Table 1 shows the responses of farmers to three categories of yield constraints, namely technical, biophysical and institutional.

Table 1: Responses of South African wheat farmers to questions regarding yield constraints of irrigation wheat

\begin{tabular}{l|c|c}
\hline \hline \multicolumn{2}{c|}{ Category of production constraints } & $\begin{array}{c}\text { Percentage of } \\
\text { farmers }\end{array}$ \\
\hline \hline \multirow{3}{*}{ Technical } & Soil fertility constraints & 6.3 \\
\cline { 2 - 3 } & Shortage/expense of irrigation water & 52.2 \\
\cline { 2 - 3 } & Lack of high-yielding cultivars & 31.3 \\
\hline \multirow{3}{*}{ Biophysical } & Red-billed quelea birds & 18.5 \\
\cline { 2 - 3 } & Hail damage & 3.0 \\
\cline { 2 - 3 } & Heat damage & 9.4 \\
\cline { 2 - 3 } & Take-all fungus & 3.0 \\
\cline { 2 - 3 } & Insect pests and weeds & 0.0 \\
\hline \multirow{3}{*}{ Policy } & Poor soil & 0.0 \\
\cline { 2 - 3 } & Poor research support and extension & 12.5 \\
\cline { 2 - 3 } & High input cost for electricity and fertilisers & 68.8 \\
\hline
\end{tabular}

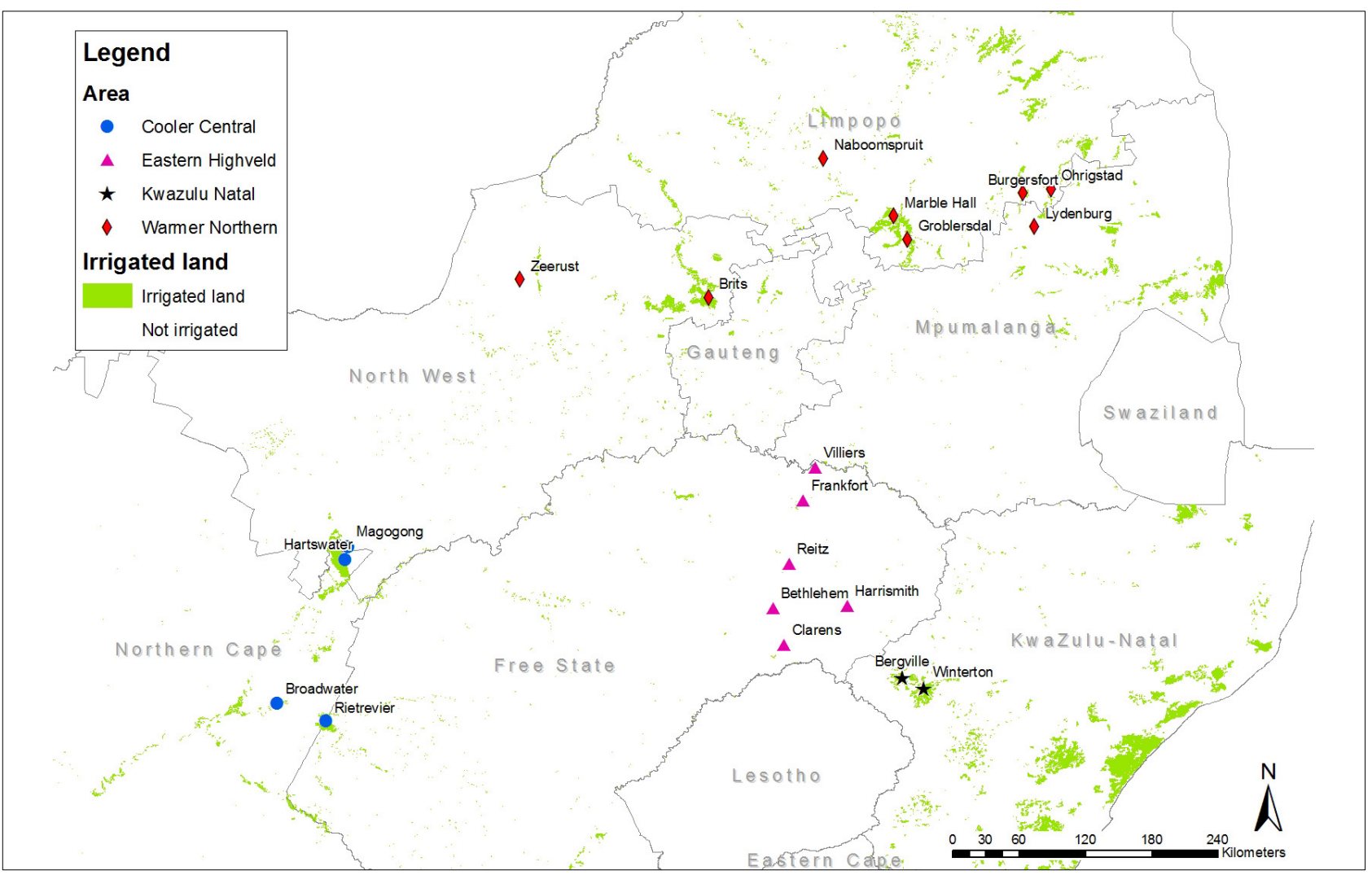

Figure 1: Map showing the locations of various irrigation wheat producers who participated in the study. 
The most frequent response on technical constraints was inadequate water for irrigation, followed by a lack of high-yielding cultivars. The biophysical constraints of major concern were red-billed quelea birds (Quelea quelea) and heat damage. There was very little to no concern about weeds, animal pests and diseases of wheat as being major yield constraints. On the policy constraints, nearly all the farmers (93.8\%) cited low wheat market price and high input cost as the major reasons for low wheat yields. The reasoning behind this is that the farmers are not making much profit from wheat, hence they are reluctant to invest in crop management efforts that would increase wheat yields. As one farmer said: 'Everything about how you manage a wheat crop boils down to the market price of wheat'. Further detail regarding the other constraints observed, as well as those reported by the farmers, is presented in subsequent sections.

\section{Water management constraints}

Inadequate water supply during critical periods of crop growth was pointed out as a major yield constraint by the majority of the farmers, hence this issue deserves further discussion. As a winter crop, wheat grown in summer rainfall areas is almost wholly dependent on irrigation for growth and yield, therefore adequate irrigation is indeed critical, especially during flowering and grain filling periods. In the warmer areas, irrigation also serves to cool crops during hot weather periods and minimises yield losses. The major problem is that for most irrigation farmers, wheat competes directly for water with their summer crops such as maize (Zea mays L.). There is sometimes a tendency to save some water for the subsequent irrigation maize. Other farmers stated that during peak demand on hot days, the irrigation requirement is so high that they just cannot keep up with the irrigation cycles, and electricity bills. Water shortages, because of rationing, was also mentioned as part of the problem by irrigation wheat farmers in the Vaalharts and Riet River irrigation schemes.

Farmers also indicated that they wished to have 'water-efficient' irrigation wheat cultivars, i.e. irrigation cultivars that produce more grain with less water applied. Limited research has been carried out in this regard in South Africa. A change in policy would be required in order to subsidise the electricity costs of irrigation wheat farming. On the other hand, field surveys also showed that water wastage through overwatering was rampant on some irrigation wheat farms, mostly because of leaking old irrigation infrastructure. Farmers are indeed aware of the importance of proper irrigation scheduling, and nearly all of them $(86 \%)$ had automated irrigation scheduling equipment. It appeared that the problem of overwatering was mainly caused by leaks and uneven terrain, which results in the large pivots having ponds on certain parts.

\section{Pest management}

There were very few observations of wheat diseases on inspected fields. All the farmers indicated that they used preventative strategies against wheat diseases, and in some cases outsourced the spraying services of chemical companies. Preventative strategies included using diseaseresistant cultivars. It appeared that the majority of the commercial farmers had adequate expertise and means to manage pests of wheat, except for red-billed quelea birds. One farmer in the warmer northern irrigation areas indicated that he had stopped planting wheat because '...the quelea birds ate it all'. The problem of queleas is worse for farmers who plant early, especially in the northern parts of the country, where yield losses of up to $100 \%$ were reported. The Department of Agriculture, Land Reform and Rural Development has sole mandate to control quelea birds in terms of the Conservation of Agricultural Resources Act 43 of 1983. Farmers are supposed to report swarms and roosting sites of the queleas to facilitate their control. Queleas are also pests of summer crops such as pearl millet (Pennisetum glaucum L.) and sorghum (Sorghum bicolor (L.) Moench). Popular opinion is that their population may be on the increase because of an all-year-round supply of food. The environmental agency of the government needs to intensify efforts to control queleas, especially in the northern parts of the country.

\section{Soil fertility management}

Adequate fertiliser nutrients must be applied to wheat in order to achieve the yield potential. None of the farmers interviewed mentioned soil fertility as a major constraint, and it also appeared that some of the farmers outsourced soil fertility management to private fertiliser companies. Many fertiliser companies in South Africa actively market their fertiliser products to commercial wheat farmers, and at times provide free soil sampling and analysis services along with fertiliser packages. Nitrogenbased fertilisers currently contribute the most (up to $60 \%$ ) to total variable costs of wheat establishment, ${ }^{5}$ and are a major determinant of profitability. Intensive fertiliser use by irrigation wheat farmers should be a cause for concern as it reduces farmer profits, and thus becomes a cause of disinterest in wheat production. There are currently no recommendations for nitrogen or phosphorus fertiliser efficient cultivars on the market. It should be noted that private breeding companies in South Africa have been primarily concerned with breeding for high yields as a marketing point, with limited to no focus on input-cost reduction. Public institutions such as ARC-SG should look at the wheat production challenge more holistically and try to breed cultivars for both minimising input costs and maximising outputs.

On-farm soil fertility data from the NWCEP reports of the 2016/2017 season (Table 2) suggest that all important nutrients were adequate on all irrigation wheat fields, except for phosphorus.

Table 2: $\quad$ Soil analysis results from irrigation wheat fields in different localities for the 2016/2017 National Wheat Cultivar Evaluation Programme

\begin{tabular}{|c|c|c|c|c|c|c|}
\hline \multirow[b]{2}{*}{ Locality } & \multirow[b]{2}{*}{ pH (KCI) } & \multicolumn{5}{|c|}{ Soil nutrients (mg/kg) } \\
\hline & & $\mathbf{P}$ & K & $\mathrm{Ca}$ & $\mathrm{Mg}$ & S \\
\hline Bergville & 5.6 & 66.7 & 371.5 & 1340 & 193.4 & 17.74 \\
\hline Bergville & $4.8^{*}$ & $9.3^{*}$ & 149.5 & 1100 & 230.5 & 28.22 \\
\hline Winterton & $4.6^{*}$ & 33.2 & 120.6 & 899.0 & 170.9 & 28.35 \\
\hline Winterton & $4.6^{*}$ & 69.8 & 101.3 & 866 & 151.6 & 7.76 \\
\hline Colenso & 5.0 & $24^{*}$ & 116 & 2927 & 1410.3 & 25.66 \\
\hline Villiers & 7.0 & 69.2 & 167.9 & 809 & 185.6 & 11.39 \\
\hline Welkom & 4.7 & 32 & 119 & 799 & 162 & 28 \\
\hline Harrismith & 5.7 & $24^{*}$ & 155.7 & 762 & 121 & 19 \\
\hline Harrismith & 5.7 & $21.6^{*}$ & 201 & 1037 & 226 & 5.51 \\
\hline Clarens & 5.5 & 61.7 & 192.1 & 873 & 146.3 & 89.92 \\
\hline Prieska & 7.7 & 46.5 & 369.9 & 2013 & 447.3 & 39.87 \\
\hline Modder River & 5.7 & 59.1 & 266.1 & 559 & 113.2 & 9.31 \\
\hline Hopetown & 6.1 & 41.7 & 241.6 & 2243 & 404.2 & 8.17 \\
\hline Riet River & 5.2 & 34.3 & 110.8 & 300 & 76.2 & 2.37 \\
\hline Modder River & $4.1^{*}$ & 54.0 & 152.4 & 438 & 103.9 & 3.22 \\
\hline Douglas & $4.0^{*}$ & 77.3 & 249.9 & 2620 & 292.2 & 157.90 \\
\hline Barkley West & 7.2 & 100.3 & 267.6 & 936 & 202.1 & 28.31 \\
\hline Prieska & 5.6 & 41.0 & 75.3 & 1248 & 363.4 & 1.86 \\
\hline Rama & 5.8 & 53.4 & 298.2 & 2116 & 478.2 & 5.56 \\
\hline Hopetown & 6.8 & 80.1 & 428.8 & 3264 & 419.9 & 15.68 \\
\hline Brits & 7.0 & $6.0^{*}$ & 234.0 & 7800 & 1512.7 & 44.08 \\
\hline Burgersfort & 7.6 & 69.5 & 257.5 & 837 & 363.6 & 7.34 \\
\hline Groblersdal & 6.8 & $21.1^{*}$ & 192.4 & 1023 & 558.2 & 47.55 \\
\hline Hartswater & 7.1 & 46.9 & 410.7 & 1118 & 226.7 & 251.15 \\
\hline Koedoeskop & 6.8 & 12.6 & 93.5 & 2431 & 895.6 & 35.33 \\
\hline Makoppa & 7.5 & 39.9 & 233.4 & 1073 & 404.5 & 8.09 \\
\hline Ohrigstad & 7.5 & 67.0 & 361.4 & 2779 & 840.1 & 9.24 \\
\hline Potchefstroom & 7.0 & $21.9^{\star}$ & 51.1 & 768 & 255.7 & 56.89 \\
\hline Skuinsdrif & 6.1 & 51.1 & 224.0 & 2253 & 803.9 & 13.40 \\
\hline Upington & 6.4 & 50.6 & 304.2 & 2002 & 442.8 & 5.99 \\
\hline Vaalharts & 6.2 & 43.4 & 226.5 & 583 & 193.0 & 13.44 \\
\hline
\end{tabular}

*Soils with acidity and phosphorus problems

Acidity problems were also evident on some farms, especially in KwaZuluNatal and the highveld regions. Phosphorus is known to be a difficult nutrient to manage, especially in no-till systems. Further research efforts 
are required in order to evaluate some production practices that could be used to enhance the availability of phosphorus in the soil for wheat crops.

\section{Cereal-based monocropping}

Farmer interviews and field observations revealed that most irrigation wheat farmers in the cooler and central irrigation areas practice 'wheat on maize' rotations. In sustainable agriculture, monocrops are strongly discouraged because they cause pest build-up, as well as soil fertility depletion. The general rule of thumb is that crops that belong to the same family should never be sown in succession. A good crop rotation increases yield and profit, and allows for sustained production. ${ }^{6}$ Monocropping causes annual yield depressions of $5-20 \%$, and no amount of fertiliser or pesticide can compensate completely for that difference. ${ }^{6}$ The causes of the rotation effect are not well understood, but improvements in soil physical properties and soil organic matter probably play a beneficial role in rotations that include legumes. It is common knowledge amongst commercial farmers that monocropping is not good for the soil, and it is important to understand the reasons for this continued practice by farmers.

Farmers in the cooler central and warmer northern irrigation areas pointed out that they practise wheat on maize rotation for economic benefits. Wheat is the only winter crop option for the farmers. Planting wheat on maize allows the farmers to double crop and achieve two crops in one year, which makes the system more profitable through maximising resource utilisation. Some farmers mentioned that they plant wheat on maize continuously because it is much more profitable and easier for them than rotating wheat with soya bean (Glycine max L.). The farmers pointed out that the cereals-only system was attractive for them because of the ease of management and marketing, and the associated lower risk due to reduced up-front costs and more reliable performance in difficult seasons. In wet conditions under centre pivots, soya beans can suffer many devastating disease problems that can require expensive chemical control measures. In conditions of water scarcity, soya beans are much more sensitive than maize to hot and dry conditions. The farmers also mentioned that they were very aware that they probably missed the yield potential of wheat because of monocropping. In search of solutions to close wheat yield gaps, research support for the current intensive wheat-maize cropping systems needs to be maintained. This scenario is likely to be better accepted by farmers. Apart from their profitability, intensive cereal cropping systems provide the added benefit of high crop residue biomass yields for feeding livestock, especially given that most South African farmers practise mixed crop and livestock farming.

\section{Policy constraints}

It is well known that policies have significantly influenced farming practices in South Africa. ${ }^{7,8}$ The liberalisation of wheat marketing, for example, is partly blamed by many farmers for precipitating the current wheat crisis. Farmers' capacity and willingness to adopt new and improved technologies and implement best management practices depend on the profitability of the crop. Policy initiatives that increase the profitability of wheat farming or ensure a competitive price for what they produce will increase the willingness of the commercial farmers of South Africa to adopt management systems and technologies that improve yield. Some suggestions include electricity and fertiliser subsidies, as well as preferential water allocation for irrigation wheat farmers.

\section{Research scientists' perspectives on irrigation wheat yield constraints}

In this section, insights from wheat scientists and industry experts on the research priorities for increasing irrigated wheat yields in South Africa are provided. A summary of the main findings is presented in Table 3.

\section{Cultivar choice}

It can be noted from Table 1 that some farmers expressed the unavailability of high-yielding cultivars as the primary reason for poor irrigation wheat yields. For various confidentiality reasons, most farmers interviewed were reluctant to disclose information on the specific cultivars which they had planted during the season. Such information could have been useful in determining the popularity of different cultivars. Nonetheless, many researchers interviewed were of the opinion that irrigation wheat farmers were not fully embracing the newest, most well-adapted and high-yielding cultivars, and hence were sometimes experiencing low yields. This issue was also thought to be related to practices such as seed retention by the farmers, as well as risk avoidance through adherence to a tried-and-tested cultivar. There are many irrigation wheat cultivars currently on the market from which farmers can choose.

Table 3: $\quad$ Responses of South African wheat experts to questions regarding yield constraints of irrigation wheat $(N=47)$

\begin{tabular}{c|l}
\hline \hline Category & \multicolumn{1}{c}{ Specification } \\
\hline \hline & $\begin{array}{l}\text { Fungal diseases: fusarium head blight (Fusarium graminearum) } \\
(n=17), \text { stem rust }(n=15), \text { take-all }(n=5), \text { powdery mildew }\end{array}$ \\
& $\begin{array}{l}\text { Blumeria graminis f. sp. tritici) }(n=7), \text { stripe rust (Puccinia } \\
\text { striiformis f.sp. tritici) }(n=15), \text { leaf rust (Puccinia triticina) }(n=14)\end{array}$ \\
\cline { 2 - 2 } Technical & Poor soil fertility $(n=2)$ \\
\cline { 2 - 2 } & Poor cultivar choice $(n=11)$ \\
\hline \multirow{2}{*}{ Biophysical } & $\begin{array}{l}\text { Abiotic stresses: lodging }(n=2), \text { frost damage }(n=1), \text { pre- } \\
\text { harvest sprouting }(n=2)\end{array}$ \\
\hline
\end{tabular}

Seed pricing is generally the same across South African seed companies, and it is only the newer cultivars that tend to cost a bit more. This difference between the newer and older cultivars is usually not more than ZAR500 per $50-\mathrm{kg}$ bag. It should also be noted that seed costs typically contribute less than $5 \%$ of establishment costs for a commercial irrigation wheat crop in South Africa, ${ }^{4}$ hence lower seed price is seldom the major reason for choosing a lower yielding cultivar over a higher yielding one.

Mean yield of different cultivars from the NWCEP is presented to show the importance of cultivar choice in irrigation wheat production (Table 4).

Table 4: Mean irrigation wheat yields of different cultivars in the production systems of South Africa, based on on-farm yield data from the 2016/2017 National Wheat Cultivar Evaluation Programme results

\begin{tabular}{l|c|c|c|c}
\hline \hline & \multicolumn{4}{|c}{ Mean grain yield (t/ha) } \\
\hline \hline \multicolumn{1}{c|}{ Cultivar } & $\begin{array}{c}\text { Cooler } \\
\text { central areas }\end{array}$ & $\begin{array}{c}\text { Warmer northern } \\
\text { areas }\end{array}$ & Highveld & KwaZulu-Natal \\
\hline \hline Duzi & 9.36 & 7.20 & 6.67 & 6.82 \\
\hline Krokodil & 10.06 & 8.14 & 6.85 & 6.68 \\
\hline PAN 3400 & 10.12 & 7.29 & 7.33 & 7.07 \\
\hline PAN 3471 & 10.08 & 6.50 & 7.34 & 6.65 \\
\hline PAN 3497 & 9.88 & 6.90 & 8.38 & 5.95 \\
\hline PAN 3515 & 9.15 & 6.78 & 7.24 & 7.23 \\
\hline PAN 3623 & 8.71 & 7.79 & 6.94 & 6.81 \\
\hline Sabie & 9.09 & 6.73 & 6.89 & 5.52 \\
\hline SST 806 & 9.76 & 7.21 & 7.17 & 6.81 \\
\hline SST 8125 & 9.56 & 7.00 & 7.31 & 6.76 \\
\hline SST 8135 & 9.63 & 7.27 & 7.10 & 7.21 \\
\hline SST 8154 & 8.95 & 7.09 & 6.83 & 7.35 \\
\hline SST 8155 & 9.13 & 6.90 & 7.15 & 5.83 \\
\hline SST 835 & 9.57 & 7.04 & 7.40 & 6.56 \\
\hline SST 843 & 7.62 & 7.60 & 6.64 & 6.20 \\
\hline SST 866 & 9.64 & 7.68 & 6.43 & 5.89 \\
\hline SST 875 & 9.35 & 7.62 & 7.05 & 6.26 \\
\hline SST 877 & 9.09 & 6.85 & 6.99 & 6.85 \\
\hline SST 884 & 9.45 & 8.01 & 6.66 & 6.90 \\
\hline SST 895 & 9.45 & 7.57 & 6.89 & 6.86 \\
\hline Mean & 9.38 & 7.26 & 7.06 & 6.61 \\
\hline *Difference & $\mathbf{2 . 5 6}$ & $\mathbf{1 . 6 4}$ & 1.95 & 1.83 \\
\hline & & & & \\
\hline
\end{tabular}

*Difference between highest-yielding and lowest-yielding cultivar 
These data were collected from cultivar trials that were replicated across many locations in each of the production regions. As shown in the table, cultivar choice is an extremely important decision in yield improvement, as the difference between the highest yielding cultivar and the lowest yielding cultivar can range from $1.64 \mathrm{t} / \mathrm{ha}$ to $2.56 \mathrm{t} / \mathrm{ha}$ within a season.

Analyses of the relative performance of irrigation wheat cultivars released in South Africa over the period 1998-2013 by Dube et al. ${ }^{10}$ showed genetic yield stagnation for cultivars produced in KwaZuluNatal and warmer northern irrigation areas. In the cooler central areas, the genetic yield gain was only $0.4 \%$ per year. Meanwhile, stagnation of genetic wheat yield progress has been reported from many other places across the globe. ${ }^{11,12}$ The prospects of obtaining new cultivars that have higher genetic yield potential are getting poorer. Meanwhile, it is necessary to place stronger emphasis on the need for farmers to fully exploit the yield potential of current cultivars, through best practices in crop management. Farmers are primarily concerned with profit, which is a function of yield and input cost. Much more focus should thus be placed on soil management and agronomy research aimed at reducing fertiliser, tillage and irrigation requirements of wheat.

\section{Poor crop stands}

Poor crop stands were observed in many irrigation wheat fields, where stand counts were far below the recommended populations for yield potential. There was also a suspicion highlighted by expert research scientists that most irrigation wheat farmers fail to calibrate their planters correctly because they do not incorporate the individual kernel weight of specific cultivars in their seed rate formulae. Kernel weight data in Table 5 show that there is considerable variation across cultivars, and in some cases, differences of nearly $100 \%$ in seed weight. A good comparison is the cultivar SST 806 (27.2 $\mathrm{g} / 1000$ kernels) compared to Krokodil ( $50 \mathrm{~g} / 1000$ kennels). The ignorance of many farmers on this matter was confirmed through surveys as most of the farmers expressed that they did not consider 1000 kernel weight in their calculations for planting density and planter calibration.

Table 5: Variations in thousand kernel mass across cultivars, and corresponding seeding density required for optimising yield of different cultivars

\begin{tabular}{|c|c|c|c|}
\hline \multirow{3}{*}{ Cultivar } & \multirow{3}{*}{$\begin{array}{c}1000 \text { kernel } \\
\text { mass } \\
\text { (g/1000 kernels) }\end{array}$} & \multicolumn{2}{|c|}{$\begin{array}{l}\text { Seeding density ( } \mathrm{g} / \mathrm{plot}) \text { required for } \\
\text { optimising yield }\end{array}$} \\
\hline & & Highveld & KwaZulu-Natal \\
\hline & & (225 plants/m²) & (275 plants $\left./ \mathrm{m}^{2}\right)$ \\
\hline Duzi & 42.0 & 140.0 & 171.1 \\
\hline Krokodil & 50.0 & 166.7 & 203.7 \\
\hline PAN 3400 & 37.1 & 123.7 & 151.2 \\
\hline PAN 3471 & 44.8 & 149.2 & 182.3 \\
\hline PAN 3497 & 39.5 & 131.5 & 160.7 \\
\hline PAN 3515 & 36.6 & 121.8 & 148.9 \\
\hline PAN 3623 & 45.3 & 150.9 & 184.5 \\
\hline Sabie & 47.5 & 158.3 & 193.5 \\
\hline SST 806 & 27.2 & 90.8 & 111.0 \\
\hline SST 8125 & 30.6 & 101.9 & 124.6 \\
\hline SST 8135 & 29.9 & 99.7 & 121.9 \\
\hline SST 8154 & 28.3 & 94.3 & 115.2 \\
\hline SST 8155 & 30.4 & 101.4 & 123.9 \\
\hline SST 835 & 26.8 & 89.3 & 109.1 \\
\hline SST 843 & 30.9 & 102.9 & 125.8 \\
\hline SST 866 & 25.4 & 84.7 & 103.5 \\
\hline SST 875 & 23.4 & 78.1 & 95.5 \\
\hline SST 877 & 26.7 & 88.9 & 108.6 \\
\hline SST 884 & 29.2 & 97.3 & 119.0 \\
\hline SST 895 & 29.4 & 98.0 & 119.8 \\
\hline
\end{tabular}

\section{Wheat diseases}

Six diseases caused by fungal pathogens were identified as the most problematic causes of yield loss for irrigated wheat in South Africa, as shown in Table 3. Three physiological disorders - namely lodging, frost damage and pre-harvest sprouting - were also considered important. Fusarium head blight (Fusarium graminearum) was mentioned most frequently as a problematic disease in all irrigation areas. Very few such diseases were observed on farmers' fields through inspection. We note with concern that many scientific research articles on wheat production constraints in South Africa are typically sentimental and tend to report impressively high potential yield losses and large areas that are at risk without much scientific basis as they try to justify their studies. Results show that different wheat scientists have diverse views on the most important causes of yield loss on irrigated wheat fields in South Africa, and these views tend to be biased towards area of specialisation for the individual scientists.

\section{Is wide-scale promotion of conservation agriculture the solution?}

Conservation agriculture has gained acceptance among policymakers in South Africa as the ideal farming approach for sustainable crop yield improvement, and there currently are calls on all farmers in the country to adopt the practice. Farm surveys show that many farmers in the KwaZuluNatal production region have moved away from conventional farming towards conservation agriculture. By definition, conservation agriculture is a concept for resource saving in agricultural crop production that strives to achieve acceptable profits along with high and sustained production levels, while concurrently conserving the environment. ${ }^{13}$ The three principles of conservation agriculture are (1) minimal mechanical soil disturbance, (2) permanent organic soil cover through cover crops and diversified crop rotations and (3) associations with various species that include legumes. These three principles are known to result in crop yield improvement if applied correctly, holistically and simultaneously. ${ }^{14,15}$ There is also much published literature on situations whereby the practice of conservation agriculture resulted in crop yield depression. ${ }^{16}$ Conversations with most irrigation wheat farmers in other parts of the country revealed that they were fully aware of the envisaged benefits of conservation agriculture, but were reluctant to adopt it. Some of the farmers indicated that they had tried it, but that it did not work for them.

There is a recent publication ${ }^{17}$ which provides worldwide data to show that no-till negatively impacts crop yields by $5.7 \%$. The authors concluded that the meta-analysis of crop production data indicated that no-till is limiting rather than enhancing global crop production and sustainable intensification efforts. However, they recommended that continuous no-till was important for reducing environmental degradation, and that if continuous no-till is carried out along with the other two conservation agriculture principles (crop rotation and use of cover crops), it often represents a more profitable management system, because of reduced energy/diesel costs related to tillage rather than yield benefit. Indeed, reduced fuel and labour costs, soil conservation and soil fertility improvement were the most commonly stated reasons for adoption of no-till and other conservation agriculture principles by farmers in KwaZulu-Natal. To help close the yield gap with conventional tillage, these findings suggest that implementing no-till should not be recommended as the first step towards conservation agriculture in cropping systems in which residue retention and crop rotation are absent.

\section{Conclusion and recommendations}

In South Africa, yield gaps of irrigation wheat are high, owing to various technical, biophysical, and institutional and policy issues. Through field surveys and farmer and researcher interviews, we explored opportunities to improve yield in a sustainable manner for irrigation wheat farmers. The dominant constraint to irrigation wheat yield is probably a low market price/value which makes farmers reluctant to invest in inputs for increasing wheat yield, and also to apply cost-cutting measures that have yield penalties. Cultivar choice was shown to be an important decision in improving irrigation wheat yield in South Africa. Other significant direct yield-reducing factors - as observed from irrigation wheat fields and confirmed by farmers - are quelea bird damage, low plant stands, phosphorus deficiency, soil acidity and water shortages. Most wheat 
scientists were of the view that constraints to yield are due to poor cultivar choice and wheat diseases. Farmers attributed water problems during peak demand as the main cause of low yields, especially in the cooler central and warmer northern irrigation areas. It is also noted that the perceptions of researchers regarding the major yield constraints of irrigation wheat were quite different from those of the farmers. A general recommendation is that researchers must work closely with farmers to develop farmerbased technologies that are easily acceptable to farmers to help remove constraints on yield as well as improve farmer profits. While breeding for yield, the focus should also be on reducing input requirements, such as water and fertilisers. The wheat industry needs cultivars that are water and fertiliser efficient for improving profitability of wheat farming. Future research efforts must focus on resource-conserving technologies for sustainable management of intensive cereal-based cropping systems of South Africa, rather than conservation agriculture per se. A well-supported agronomy research wing for wheat already exists in the form of the ARCSG. Funding for agronomic research aimed at refining wheat production practices towards reducing production costs in this unit should be increased. Considering the constraints highlighted in this study, there is a need for more government resources and commitment in terms of policy to set in motion necessary actions to support irrigation wheat farmers.

\section{Acknowledgements}

We thank the Production Systems Division of the ARC-SG, headed by Mr Willem Kilian. The Winter Cereal Trust and National Research Foundation (South Africa) are acknowledged for funding the yield gaps of irrigation wheat project in South Africa, from which this study emerged.

\section{Authors' contributions}

All authors contributed equally to the writing of the manuscript. Additionally, E.D. and N.Z.S. performed the surveys and analysed the data. T.J.T. made conceptual contributions to the study as the Senior Research Manager at ARC-SG. M.F. assisted in data analyses and discussion of the findings.

\section{References}

1. Stats SA. Abstract of agricultural statistics. Pretoria: Department of Agriculture; 2013.

2. Agricultural Policy Action Plan (APAP) 2015-2019. Pretoria: Department of Agriculture, Forestry and Fisheries; 2014.

3. Van Ittersum MK, Cassman KG, Grassini P, Wolf J, Tittonell P, Hochman Z. Yield gap analysis with local to global relevance - A review. Field Crops Res. 2013;143:4-17. https://doi.org/10.1016/j.fcr.2012.09.009
4. Sosibo NZ, Muchaonyerwa P, Visser L, Barnard A, Dube E, Tsilo TJ. Soil fertility constraints and yield gaps of irrigation wheat in South Africa. S Afr J Sci. 2017;113(1-2), Art. \#2016-0141, 9 pages. https://doi.org/10.17159/ sajs.2017/20160141

5. Van der Westhuizen L, Trapnell L. How do we compare with "down under"? - Measuring and comparing the competitiveness of South African wheat industry with Australia. SA Graan/Grain. 2015 February;51-57.

6. Bullock DG. Crop rotation. Crit Rev Plant Sci. 1992;11(4):309-326. https:// doi.org/10.1080/07352689209382349

7. Binswanger HP, Deininger K. South African land policy: The legacy of history and current options. World Dev. 1993;21:1451-1475. https://doi. org/10.1016/0305-750X(93)90127-U

8. Greenberg S. PLAAS research report 40: Status report on land and agricultural policy in South Africa. Cape Town: Institute for Poverty, Land and Agrarian Studies, School of Government, University of the Western Cape; 2010.

9. Keswell M, Carter MR. Poverty and land redistribution. J Dev Econ. 2014;110:250-261. https://doi.org/10.1016/j.jdevec0.2013.10.003

10. Dube E, Kilian W, Mwadzingeni L, Sosibo NZ, Barnard A, Tsilo TJ. Genetic progress of spring wheat grain yield in various production regions of South Africa. S Afr J Plant Soil. 2019:36(1):33-39. https://doi.org/10.1080/02571 862.2018.1469793

11. Oury FX, Godin C, Mailliard A, Chassin A, Gardet 0 , Giraud A, et al. A study of genetic progress due to selection reveals a negative effect of climate change on bread wheat yield in France. Eur J Agron. 2012;40:28-38. https://doi. org/10.1016/j.eja.2012.02.007

12. Hall AJ, Richards RA. Prognosis for genetic improvement of yield potential and water-limited yield of major grain crops. Field Crops Res. 2013;143:18-33. https://doi.org/10.1016/j.fcr.2012.05.014

13. Dumanski J, Peiretti R, Benetis J, McGarry D, Pieri C. The paradigm of conservation tillage. Proceedings of World Association of Soil and Water Conservation. Rome: FA0; 2006. p. 58-64.

14. Bolliger A, Magid J, Amado JCT, Neto FS, Dos Santos Ribeiro MDF, Calegari A, et al. Taking stock of the Brazilian "Zero-Till Revolution": A review of landmark research and farmers' practice. Adv Agron. 2006;91:47-110. https://doi. org/10.1016/S0065-2113(06)91002-5

15. Food and Agriculture Organization of the United Nations (FAO). Investing in sustainable agricultural intensification: The role of conservation agriculture. A framework for action. Rome: FAO; 2008.

16. Giller $\mathrm{KE}$, Witter $\mathrm{E}$, Corbeels $\mathrm{M}$, Tittonell $\mathrm{P}$. Conservation agriculture and smallholder farming in Africa: The heretics' view. Field Crop Res. 2009;114:23-34. https://doi.org/10.1016/j.fcr.2009.06.017

17. Pittelkow CM, Liang X, Linquist BA, Van Groenigen KJ, Lee J, Lundy ME, et al Productivity limits and potentials of the principles of conservation agriculture. Nature. 2015;517(7534):365. https://doi.org/10.1038/nature13809 